\title{
Geomechanical rock properties of a basaltic volcano
}

\author{
Lauren N. Schaefer ${ }^{1 *}$, Jackie E. Kendrick ${ }^{2}$, Thomas Oommen ${ }^{1}$, Yan Lavallée ${ }^{2}$ and \\ Gustavo Chigna ${ }^{3}$
}

'Department of Geological and Mining Engineering and Sciences, Michigan Technological University, Houghton, MI, USA,
${ }^{2}$ Department of Earth, Ocean and Ecological Sciences, University of Liverpool, Liverpool, UK, ${ }^{3}$ Departamento de
Vulcanología, Instituto Nacional de Sismología, Vulcanología, Meteorología e Hidrología, Guatemala City, Guatemala

OPEN ACCESS

Edited by:

Antonio Costa,

Istituto Nazionale di Geofisica e

Vulcanologia, Italy

Reviewed by:

Oleg E. Melnik,

Moscow State University, Russia

Corrado Cimarelli,

Ludwig-Maximilians-Universität

München, Germany

*Correspondence:

Lauren N. Schaefer,

Department of Geological and Mining

Engineering and Sciences, Michigan

Technological University, 630 Dow

ESE Building, 1400 Townsend Drive,

Houghton, MI 49931, USA

Inschaef@mtu.edu

Specialty section:

This article was submitted to

Volcanology,

a section of the journa

Frontiers in Earth Science

Received: 20 March 2015

Accepted: 28 May 2015

Published: 09 June 2015

Citation:

Schaefer LN, Kendrick JE, Oommen T,

Lavallée Y and Chigna G (2015)

Geomechanical rock properties of a

basaltic volcano.

Front. Earth Sci. 3:29.

doi: 10.3389/feart.2015.00029
In volcanic regions, reliable estimates of mechanical properties for specific volcanic events such as cyclic inflation-deflation cycles by magmatic intrusions, thermal stressing, and high temperatures are crucial for building accurate models of volcanic phenomena. This study focuses on the challenge of characterizing volcanic materials for the numerical analyses of such events. To do this, we evaluated the physical (porosity, permeability) and mechanical (strength) properties of basaltic rocks at Pacaya Volcano (Guatemala) through a variety of laboratory experiments, including: room temperature, high temperature $\left(935^{\circ} \mathrm{C}\right)$, and cyclically-loaded uniaxial compressive strength tests on as-collected and thermally-treated rock samples. Knowledge of the material response to such varied stressing conditions is necessary to analyze potential hazards at Pacaya, whose persistent activity has led to 13 evacuations of towns near the volcano since 1987 . The rocks show a non-linear relationship between permeability and porosity, which relates to the importance of the crack network connecting the vesicles in these rocks. Here we show that strength not only decreases with porosity and permeability, but also with prolonged stressing (i.e., at lower strain rates) and upon cooling. Complimentary tests in which cyclic episodes of thermal or load stressing showed no systematic weakening of the material on the scale of our experiments. Most importantly, we show the extremely heterogeneous nature of volcanic edifices that arise from differences in porosity and permeability of the local lithologies, the limited lateral extent of lava flows, and the scars of previous collapse events. Input of these process-specific rock behaviors into slope stability and deformation models can change the resultant hazard analysis. We anticipate that an increased parameterization of rock properties will improve mitigation power.

Keywords: volcanic materials, mechanical properties, high temperature, strength, Pacaya volcano

\section{Introduction}

Several studies of non-volcanic slopes using numerical models and geomechanical material properties have been adapted for the investigation of volcanic collapses, slope stability, and ground deformation. These include applying Limit Equilibrium Methods (LEM) (Voight et al., 1983; Iverson, 1995; Elsworth and Voight, 1996; Hürlimann et al., 2000; Reid et al., 2000; Donnadieu et al., 2001; Okubo, 2004; Apuani and Corazzato, 2010) and numerical modeling by Distinct Element Methods (DEM) (Zimbelman et al., 2004), Finite Difference Methods (FDM) (Hürlimann et al., 2000; Apuani et al., 2005a,b, 2007; Apuani and Corazzato, 2010) and Finite Element Methods 
(FEM) (Sousa and Voight, 1995; Apuani and Corazzato, 2010; del Potro et al., 2013; Schaefer et al., 2013). However, numerical data on the relevant mechanical properties for volcanic rocks and rock masses used in these types of studies remain a major source of uncertainty. Quantifying these properties is challenging due to the diversity of materials that compose volcanoes, the unknown interior structures and geometry, and the often inaccessible locations of volcanic rock masses (Thomas et al., 2004; del Potro and Hürlimann, 2008).

Experimental rock mechanics has traditionally been executed in the fields of civil engineering and mining as well as structural geology, with a focus on sedimentary and intrusive igneous rock (see Paterson and Wong, 2005 and references therein). Early efforts were made to understand rock behavior and strength under high pressure (Scholz, 1968; Tapponnier and Brace, 1976; Batzle et al., 1980), high temperature (Griggs et al., 1960; Simmons and Cooper, 1978; Handin and Carter, 1979; Fredrich and Wong, 1986), and in water saturated conditions (Bauer et al., 1981). Additional work was done to connect mineralogy and microstructures with rock strength (Merriam et al., 1970; Prikryl, 2001) and to model the mechanical properties of porous material; that is, the poreemanated crack model (Sammis and Ashby, 1986) and the wing-crack model (Ashby and Sammis, 1990). Only recently have laboratory studies begun to systematically investigate the microstructural, physical, and mechanical properties of volcanic rocks, a material infamously known for its formation under disequilibrium conditions, thereby rich in heterogeneities at all scales. These include experiments on a range of material under relevant volcanic conditions such as thermal stressing (Vinciguerra et al., 2005; Kendrick et al., 2013a; Heap et al., 2014a), cyclic inflation-deflation cycles by intrusions (Heap et al., 2009, 2010; Kendrick et al., 2013a), fragmentation (Spieler et al., 2004; Kueppers et al., 2006; Scheu et al., 2008), and flow or fracture at high temperatures and/or pressures (Balme et al., 2004; Rocchi et al., 2004; Smith et al., 2005; Lavallée et al., 2007, 2008; Benson et al., 2008; Cordonnier et al., 2009; Loaiza et al., 2012; Kendrick et al., 2013b).

These investigations have shown that porosity is a fundamental control on rock properties. At volcanoes, the porous network comprises of vesicles and fractures that build the permeable network and which controls degassing (Ashwell et al., 2015). Porosity also controls the mechanical response of materials whereby their strength decreases and elasticity increases with porosity (e.g., Al-Harthi et al., 1999; Spieler et al., 2004; Paterson and Wong, 2005; Heap et al., 2014a,b). Thermal stressing of rock has also been argued to affect its strength, although damage imparted by thermal cracking has been shown to lead to unsystematic changes in mechanical response (Jones et al., 1997; Rocchi et al., 2003; Balme et al., 2004; Kendrick et al., 2013a; Heap et al., 2014a); the ambiguity of this claim has been linked to the extent of pre-existing microcrack damage in a rock (Vinciguerra et al., 2005; Heap et al., 2014a). Other rocks can debilitate upon thermal stressing, as is the case during decarbonation (Heap et al., 2013b) and dehydroxylization (Heap et al., 2012) of certain rock-forming minerals. Cyclic loading can lead to mechanical weakening (Kendrick et al., 2013a) and an increase in heterogeneity of elastic modulus values, likely due to an increase in anisotropic crack damage within the samples (Heap and Faulkner, 2008; Heap et al., 2010).

This paper focuses on the challenge of characterizing volcanic materials for numerical analyses and addressing the scarcity of published geomechanical data for volcanic materials. To do this, we evaluated the mechanical properties of rocks at Pacaya Volcano (Guatemala) using a variety of laboratory experiments, including room temperature, high temperature, and cyclicallyloaded uniaxial compressive strength tests (UCS) on as-collected and thermally treated rock samples. Pacaya is an ideal case study for material characterization for use in deformation analysis due to its persistent activity, significant morphological changes, and history of slope instability (Vallance et al., 1995; Matías Gómez et al., 2012; Schaefer et al., 2013). By considering the non-unique geomechanical behaviors when the materials are subjected to this wide range of stressing conditions, we may allow the determination of more encompassing and realistic models that will help better predict volcanic processes and imminent catastrophes.

\section{Geologic Setting}

Pacaya is a basaltic stratovolcano complex in the Central American Volcanic Arc (Figure 1A) that has been persistently active since 1961 with over 250 lava flows, intermittent strombolian activity, and ash and fumarolic plumes (Matías Gómez et al., 2012; Rose et al., 2013). Between 0.6 and 1.5 ka B.P., the SW sector of the initial cone failed in a major edifice collapse, forming a debris avalanche that traveled $25 \mathrm{~km} \mathrm{SW}$, containing approximately $0.65 \mathrm{~km}^{3}$ of debris (Kitamura and Matías Gomez, 1995; Vallance et al., 1995). The edifice re-built within the collapse amphitheater until the nineteenth century, when it went into a period of repose. Activity renewed once again in 1961, loading the SW flank of the edifice with $100-150 \mathrm{~m}$ thick of primarily effusive lava flows. Although the volcano has grown substantially, the collapse scarp is still exposed today on the north and east sides of the cone on account of the asymmetric loading of material on the SW flank.

Explosive and effusive eruptions have caused constant morphometric changes to the edifice: in 1962, an oval-shaped area, approximately $300 \mathrm{~m}$ by $200 \mathrm{~m}$, subsided near the summit. This subsidence has since been in-filled by erupted material. In 2010, a large collapse trough $50-80 \mathrm{~m}$ deep and $100 \mathrm{~m}$ wide, extending $600 \mathrm{~m}$ from the summit, developed concurrently with explosive activity on May 27, 2010 (Figure 1B). Although the exact causes of these collapses are unknown, shallow magma systems and high growth rates leading to over-steepening of the cone have been postulated as factors affecting edifice stability (Eggers, 1983; Vallance et al., 1995; Matías Gómez, 2009; Schaefer et al., 2013). The rock characterization determined in this study can help to better understand events such as these and assess potential future intrusions, collapses, and deformation events. 

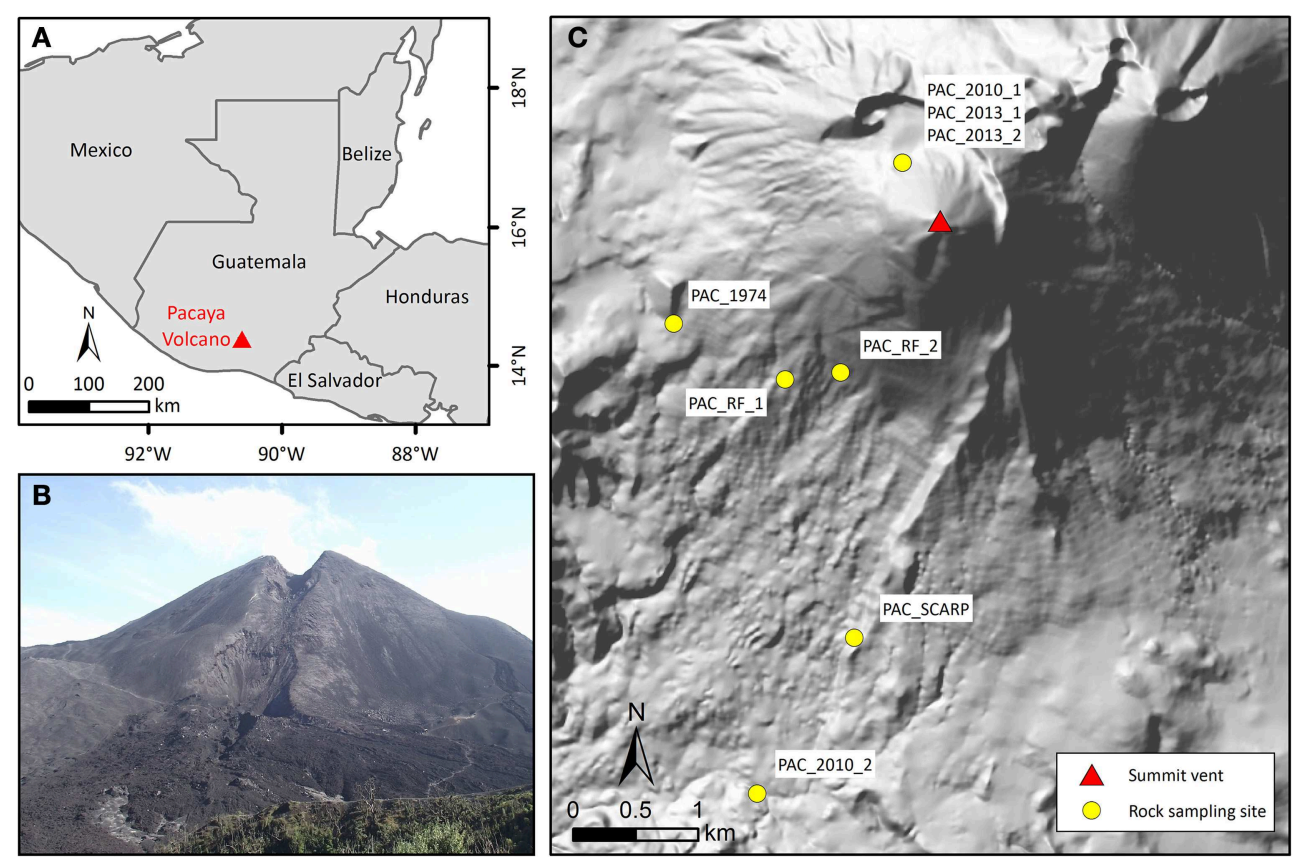

FIGURE 1 | (A) Map showing the location of Pacaya in Guatemala. (B) Photograph of Pacaya taken in January 2012, showing the 2010 collapse scar and (C) map showing the location of samples chosen for this study. See the Supplementary Image for a detailed volcanological map from Matías Gómez et al. (2012) with field site locations.

\section{Materials and Experimental Methodology}

\section{Experimental Materials Sample Characterization}

Pacaya volcano is made of diverse lithologies (lavas and volcaniclastic deposits) which vary in extent and character significantly, though non-systematically (Wunderman and Rose, 1984; Matías Gómez et al., 2012). This heterogeneity at the large scales calls for a characterization of equally diverse rock types. For this experimental study, eight sample blocks were collected from different eruptive deposits (Figure 1C, see Supplementary Image for detailed volcanological map from Matías Gómez et al., 2012), which cover a range of macroscopically representative physical properties of the edifice-forming basalt at Pacaya (Table 1). These samples, which vary in porosity, crystal size, and vesicle size distribution include: two samples north of the summit from lava flows in January and August-October of 2013; two samples of blocks from rock fall collected from on top of the 2010 deposits; two samples from lava flows associated with the May-June eruption in 2010; one sample from the brecciated top of a lava flow that occurred in February of 1974; and one sample from the ( $>1.5 \mathrm{ka}$ B.P.) southern portion of the ancestral scarp (Figures 2A-H). Typically, basalt at Pacaya is porphyritic with olivine and plagioclase phenocrysts (45 $\mathrm{wt} \%$ ), with lesser amounts of clinopyroxene and iron-titanium oxides and plagioclase dominated microlites (Bardintzeff and Deniel, 1992). No significant petrographic differences have been found between prehistoric and modern lava flows. Each of the sample blocks was drilled to prepare a series of cylindrical cores with a
TABLE 1 | Sample names and eruption date.

\begin{tabular}{ll}
\hline Sample name & Eruption date \\
\hline PAC_2013_1 & August-October, 2013 \\
PAC_RF_2 & $2010-2013$ \\
PAC_SCARP & $>0.2-4 \mathrm{ka}$ \\
PAC_2010_2 & May-June, 2010 \\
PAC_RF_1 & 2010-2013 \\
PAC_2013_2 & January, 2013 \\
PAC_2010_1 & May-June, 2010 \\
PAC_1974 & February, 1974
\end{tabular}

diameter of $26 \mathrm{~mm}$ and a length of $52 \mathrm{~mm}$ to maintain a lengthto-diameter ratio of 2:1. Although other samples were collected in the field (see Supplementary Image), the eight sample blocks were chosen from which cores could be drilled to provide the widest range of representative samples while ensuring reliable and repeatable measurements of strength. Based on the abundance of effusive products, and the similarity of eruptive product composition over time, we feel as though our samples represent the majority of edifice-building material variability.

\section{Porosity and Permeability}

Before each test, porosity was determined for each core using a $100 \mathrm{cc}$ helium pycnometer from Micromeritics, providing measurements with an accuracy of $0.1 \%$. First, the density of a cylindrical core $\left(\rho_{\text {rock }}\right)$ was estimated and used to calculate the connected porosity $\left(\phi_{\mathrm{c}}\right)$. Total porosity $\left(\phi_{\mathrm{T}}\right)$ was also determined 


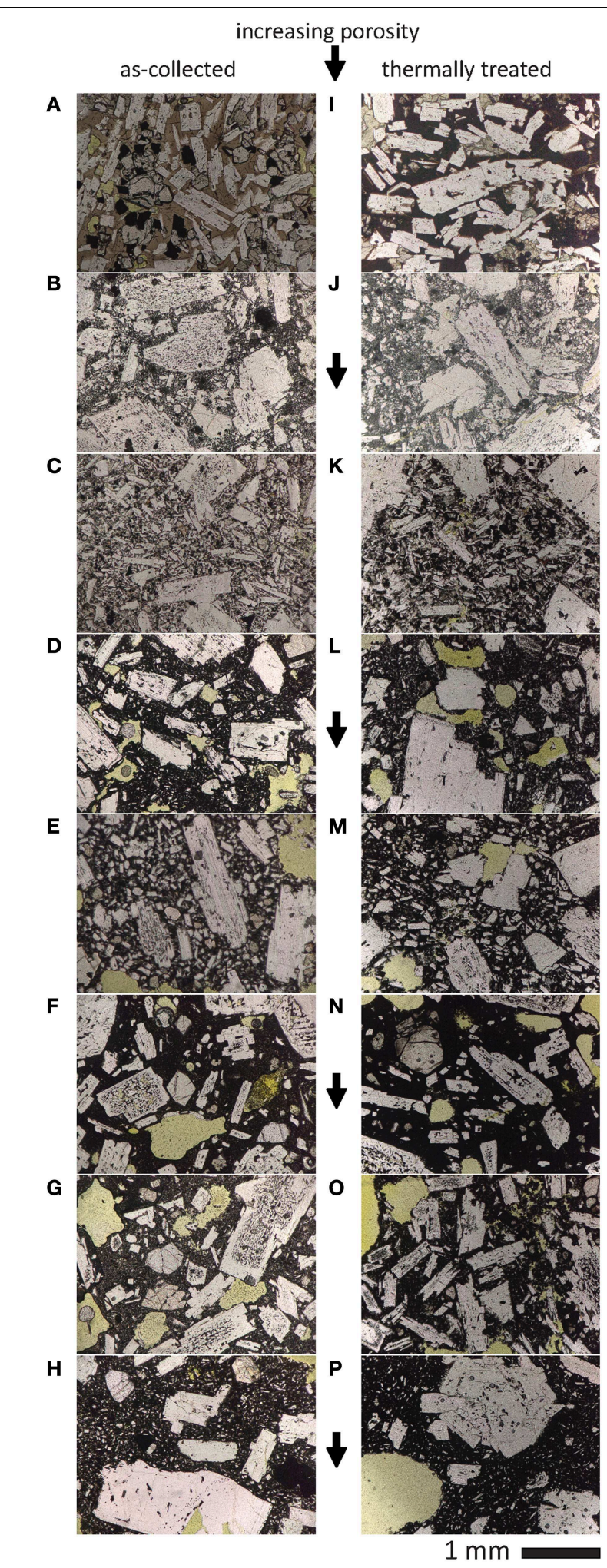

FIGURE 2 | Photomicrographs of the samples chosen for this study (Left, As-collected samples; Right, Thermally stressed samples). (A) PAC_2013_1 shows intact phenocrysts and few microlites set in a glassy groundmass; (B) PAC_RF_2 is made of large plagioclase phenocrysts (broken,

(Continued)

\section{FIGURE 2 | Continued}

sieved, and zoned) surrounded by fine grained groundmass; (C) PAC_SCARP contains fewer and smaller plagioclase phenocrysts surrounded by a mildly developed trachytic texture in the microcrystalline groundmass; (D)

PAC_2010_2 contains well-defined plagioclase and pyroxene phenocrysts as well as large deformed pores in a fine grained groundmass host of plagioclase and iron oxides; (E) PAC_RF_1 hosts large phenocrysts of plagioclase with poikilitic inclusions and equant microlites in a fine grained groundmass rich in iron oxides; (F) PAC_2013_2 shows large phenocrysts of plagioclase and pyroxene, with some microlites in a groundmass hosting very fine grained crystals. (G) PAC_2010_1 hosts large phenocrysts, rounded pores and very fine grained groundmass. (H) PAC_1974 hosts the largest phenocrysts (of the collected samples) and a fine groundmass containing equant grains. (I-P) photomicrographs of thermally stressed samples, showing a tendency for the samples groundmass to darken due to oxidation of iron oxides and possibly micro-crystallization of the groundmass, as well as the minor development of micro-fractures.

for each sample type by measuring the density of a powdered sample $\left(\rho_{\text {powder }}\right)$, and computing:

$$
\phi_{\mathrm{T}}=\left(\rho_{\text {powder }}-\rho_{\text {rock }}\right) / \rho_{\text {rock }}
$$

From this, isolated porosity was calculated by subtracting connected porosity from total porosity.

Permeability was determined for each sample block using a TinyPerm II Permeameter from New England Research Inc., which was also used to measure the permeability of $97 \mathrm{in}$-situ lavas and breccias (unconsolidated air-fall tephras to brecciated surfaces of lava flows) at Pacaya during fieldwork in October 2013.

\section{Thermal Stressing}

Thermal stressing occurs in volcanic edifices due to heat radiating from the magma in the conduit that may be upwards of $1100^{\circ} \mathrm{C}$. Rocks in direct contact with conduit magma may experience partial melting, and further afield temperatures exceeding $900^{\circ} \mathrm{C}$ are likely common. Thermal analysis was performed on cores of samples in a box furnace by heating them to $1050^{\circ} \mathrm{C}$ and then re-cooling to room temperature at a rate of $10^{\circ} \mathrm{C} / \mathrm{min}$ to assess physical changes, including oxidation and the onset of melting. This data was used to constrain the maximum experimental temperature for uniaxial compressive strength tests, as it revealed partial melting between 1000 and $1050^{\circ} \mathrm{C}$ for some samples; therefore a temperature of $935^{\circ} \mathrm{C}$ was chosen for the hightemperature tests as well as for the thermal stressing tests.

For thermal stressing, three cores from each block were placed in a box furnace and heated at a rate of $4^{\circ} \mathrm{C} / \mathrm{min}$ to the target temperature, left to dwell for $1 \mathrm{~h}$ to allow thermal equilibration and completion of any reactions which might have taken place, and then cooled to room temperature using the same rate. A rate of $4{ }^{\circ} \mathrm{C} / \mathrm{min}$ was chosen to minimize damage that could result from temperature gradients within the sample with the presumption that heating in volcanic scenarios occurs relatively steadily, except for rocks in direct contact with magma. Porosity of samples was measured before and after thermal treatment. Thin sections were made from each block with and without thermal stressing (Figures 2A-P). 


\section{Experimental Methods}

Uniaxial compressive strength (UCS) experiments were conducted at constant strain rates in a $100 \mathrm{kN}$ Instron uniaxial loading frame (model 1362) in the Experimental Volcanology Laboratory at the University of Liverpool. A summary of the experiment type, temperature, and strain rate is shown in Table 2. Applied load (in $\mathrm{kN}$ ) and displacement $(\mathrm{mm})$ were measured throughout at a rate of $10-100 \mathrm{~Hz}$. Following calibration, to take into account the compliance of the experimental set-up at the given conditions, axial stress $\left(\sigma_{a} ; \mathrm{MPa}\right)$ and strain $\left(\varepsilon_{a}\right)$ were calculated. The Static Young's modulus $\left(\mathrm{E}_{s}\right)$ was calculated from the linear portion of the stress/strain curve (at 30\% of the peak stress) via:

$$
\mathrm{E}_{s}=\mathrm{d} \sigma_{a} / \mathrm{d} \varepsilon_{a}
$$

\section{Room Temperature Experiments}

UCS experiments were performed on dry specimens at room temperature by testing three cores $(52 \mathrm{~mm}$ length and $26 \mathrm{~mm}$ diameter) from each of the eight original sample blocks as well as three thermally stressed cores from seven sample blocks. The cylindrical cores were axially loaded at strain rates of $10^{-1}, 10^{-3}$, and $10^{-5} \mathrm{~s}^{-1}(5,0.05$, and $0.0005 \mathrm{~mm} / \mathrm{s}$, respectively) until failure occurred, as defined by a sharp stress drop.

\section{Cyclic Experiments}

In cyclic experiments, the uniaxial compressive stress was applied at a constant strain rate of $10^{-5} \mathrm{~s}^{-1}$ until $15 \%$ of the sample's value of UCS (as determined from previous room temperature UCS tests at a strain rate of $10^{-5} \mathrm{~s}^{-1}$ ), then unloaded to $5 \%$ of this stress. Subsequently, a further loading/unloading cycle was imposed, but this time reaching an additional 15\% load increment (i.e., $30 \%$ of UCS), then again unloaded to $5 \%$. These cycles were repeated by increasing the peak stress in $15 \%$ stress increments of the UCS until failure. All cyclic tests were

TABLE 2 | Sample, strain rate and temperature conditions for each experiment.

\begin{tabular}{|c|c|c|c|}
\hline Experiment I.D. & Test & $\begin{array}{c}\text { Strain rate } \\
\left(\mathrm{s}^{-1}\right)\end{array}$ & $\begin{array}{c}\text { Temperature } \\
\left({ }^{\circ} \mathrm{C}\right)\end{array}$ \\
\hline a & UCS on original cores & $10^{-1}$ & 20 \\
\hline$b$ & UCS on original cores & $10^{-3}$ & 20 \\
\hline c & UCS on original cores & $10^{-5}$ & 20 \\
\hline$d$ & $\begin{array}{l}\text { UCS on thermally } \\
\text { stressed cores }\end{array}$ & $10^{-1}$ & 20 \\
\hline e & $\begin{array}{l}\text { UCS on thermally } \\
\text { stressed cores }\end{array}$ & $10^{-3}$ & 20 \\
\hline$f$ & $\begin{array}{l}\text { UCS on thermally } \\
\text { stressed cores }\end{array}$ & $10^{-5}$ & 20 \\
\hline$g$ & Cyclic loading tests & $10^{-5}$ & 20 \\
\hline $\mathrm{h}$ & $\begin{array}{l}\text { UCS at high } \\
\text { temperature }\end{array}$ & $10^{-1}$ & 935 \\
\hline i & $\begin{array}{l}\text { UCS at high } \\
\text { temperature }\end{array}$ & $10^{-5}$ & 935 \\
\hline
\end{tabular}

conducted at room temperature on dry, as-collected specimens at a strain rate of $10^{-5} \mathrm{~s}^{-1}$.

\section{High Temperature Experiments}

High temperature tests were conducted by placing a core in the same uniaxial press surrounded by a three-zone split cylinder furnace, and heated at a rate of $4^{\circ} \mathrm{C} / \mathrm{min}$ until a temperature of $935 \pm 3^{\circ} \mathrm{C}$ was reached. Before undertaking the experimental program, the compliance of the setup at high temperature was measured and considered to remove any of the mechanical artifacts of the machine on the dataset. Samples were held to thermally equilibrate at this temperature for an hour before the experiment began. Temperature was consistently monitored during heating, cooling, and while the compressive load was applied by a thermocouple in contact with the outer surface of the specimen. Samples at high temperature were tested at strain rates of $10^{-1}$ and $10^{-5} \mathrm{~s}^{-1}$ to determine end-member strain-rate behavior.

\section{Results}

\section{Porosity and Permeability}

Samples range from 2 to $48 \%$ total porosity, and isolated pores makes up a varying but sometimes substantial amount of total porosity (Figure 3) as a result of the varying abundance of microcracks and vesicles (Figure 2). Although porosity varied greatly between samples, it remained relatively constant between cores from the same sample, with standard deviations of $<3.3 \%$ for five or more measurements. Pre- and post-thermal stressing pycnometer measurements showed only minor changes in porosity of -0.4 to $+0.2 \%$ despite visible differences in sample structure that resulted from thermal cracking and/or oxidation (Figure 2). Permeability measurements showed a bimodal distribution (Figure 4A) that approximately split into coherent lavas which were sampled for this study (peak at $10^{-13}$ ), and brecciated lava flow surfaces and unconsolidated air-fall deposits (peak at $10^{-10}$ ). The sample's permeability was observed to scale to porosity via the relationship for effusive lavas constrained by Mueller et al. (2005) (Figure 4B).

\section{Uniaxial Compressive Strength Results}

Here we present the results of 64 UCS experiments and the effects of (1) strain rate, (2) porosity, (3) cyclic loading, (4) thermal stressing, and (5) temperature on the strength of the tested rocks. For all UCS stress-strain curves, see Supplementary Material.

A comparison of UCS stress-strain curves for all as-collected, room temperature cores at $10^{-1}$ and $10^{-5} \mathrm{~s}^{-1}$ strain rates is shown in Figure 5. These curves display the shape of typical brittle failure under compression, outlined in Heap et al. (2014a) as follows: (1) convex shape as microcracks aligned subperpendicular to the direction of loading begin to close (leading to a large strain despite little stress accumulation); (2) linear shape as the rock deforms elastically; (3) concave shape as the rock deforms inelastically and experiences strain hardening; and (4) rock failure marked by a substantial stress drop. Higher strain rate tests fail in a more brittle manner (marked by sharper curve 


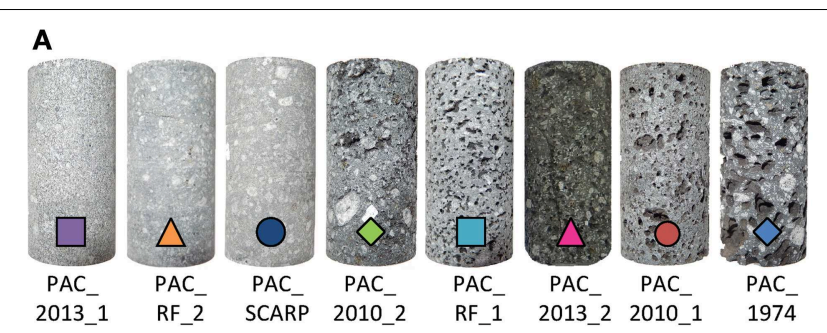

B

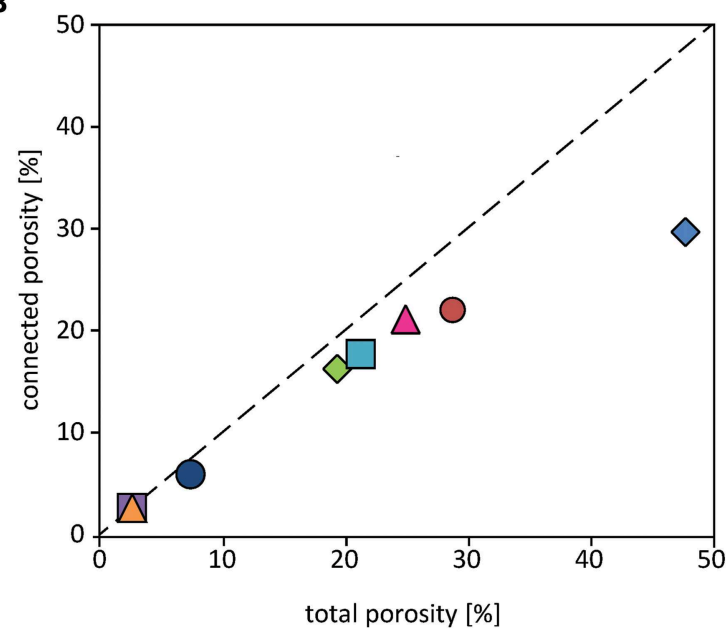

FIGURE 3 | (A) Photographs of the samples selected for this study and (B) Porosity of the samples as determined by helium pycnometry. The figure displays the fraction of connected pores against the total porosity of the samples.

peaks at the stress drop) than slower strain rates (Figure 5) and reach both a higher axial strain and a higher peak stress before failure occurs (Figure 6A). Indeed, room temperature, thermally stressed, and high temperature tests all show a clear pattern of apparent strengthening with increasing strain rates, which is more significant at lower porosity (Figure 6B, Table 3). On average, room temperature cores tested at a strain rate of $10^{-1}$ $\mathrm{s}^{-1}$ failed at axial stresses $5 \%$ higher than strain rates of $10^{-3}$ $\mathrm{s}^{-1}$, and strain rates of $10^{-3} \mathrm{~s}^{-1}$ failed $29 \%$ higher than strain rates of $10^{-5} \mathrm{~s}^{-1}$. In a similar pattern, thermally stressed cores tested at a strain rate of $10^{-1} \mathrm{~s}^{-1}$ failed at axial stresses $4 \%$ higher than strain rates of $10^{-3} \mathrm{~s}^{-1}$, and strain rates of $10^{-3} \mathrm{~s}^{-1}$ failed at a stress $22 \%$ higher than the stress at strain rates of $10^{-5} \mathrm{~s}^{-1}$. Finally, high-temperature cores failed at an average 52\% higher axial stress at $10^{-1} \mathrm{~s}^{-1}$ as compared to strain rates of $10^{-5} \mathrm{~s}^{-1}$ (Table 3).

The UCS results show that failure stress is highly dependent on porosity, with maximum stress decreasing non-linearly as porosity increases (Figure 6B). Samples can be divided into three porosity groups, with samples having $<10 \%$ porosity averaging a UCS of $138 \mathrm{MPa}$, samples with $10-25 \%$ porosity with a strength decreasing by $55 \%$ to an average of $62 \mathrm{MPa}$, and samples with $>25 \%$ porosity with a strength decreasing another $66 \%$ to an average of $21 \mathrm{MPa}$. Overall, axial compressive strength for Pacaya basalt ranges widely from 12 to $174 \mathrm{MPa}$ (Table 3), with the lower

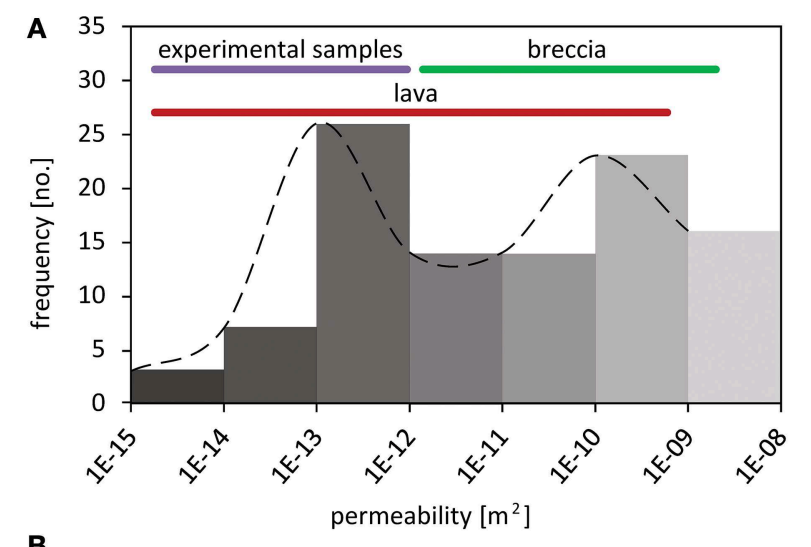

$B$

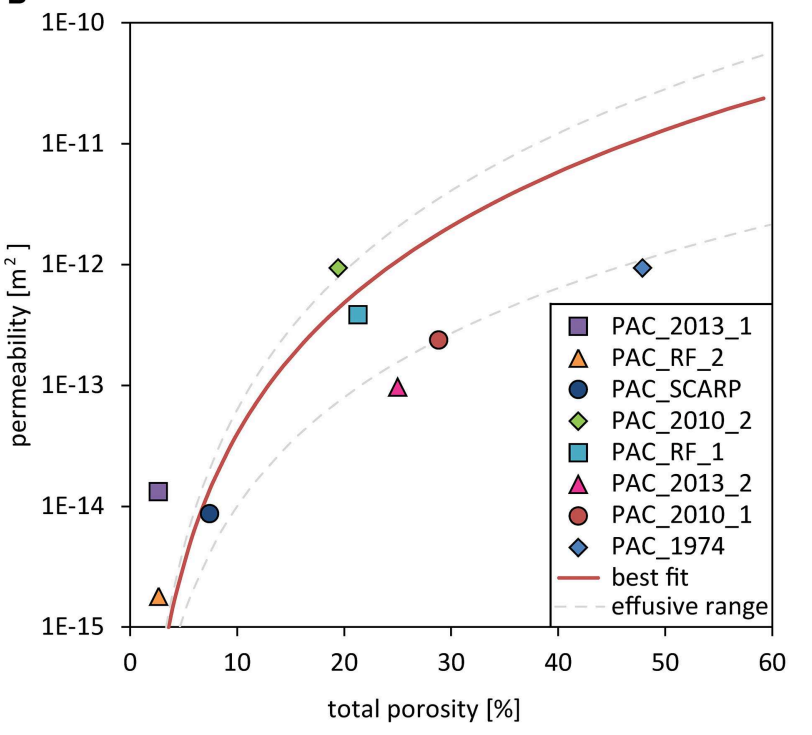

FIGURE 4 | (A) Permeability frequency of in-situ rocks at Pacaya from 97 measurements made using a portable permeameter during fieldwork in October 2013. The data shows that the permeability of lavas spans a wider range than that of breccias (defined, here as unconsolidated volcanic deposits). The samples collected for the experimental study had low relative permeability so as to constrain the strength of intact material associated with failure, such as in edifice collapse. (B) Permeability vs. porosity for each sample selected for this study. The best fit regression of the dataset falls within the porosity-permeability relationship for effusive lavas described by Mueller et al. (2005).

end falling into strength categories as low as chalk (Hoek, 1994). Given that the porosity of the rocks scales with permeability, we chose to assess the relationship of UCS with permeability, as this measures the strong control that cracks have on the physical properties of rocks. The data shows a remarkable linearity in UCS decrease with logarithmic increase in rock permeability (Figure 6C). Cyclic loading tests in which the peak load of each successive cycle was increased had a variable effect on strength (Table 3, Figure 6). Each cycle peak was $15 \%$ of the failure strength of the room temperature tests higher (as-collected cores at $10^{-5} \mathrm{~s}^{-1}$ ). The highest stress was usually reached on the final cycle, exceeding all previous stress cycles (Figures 7A,B). However, some cyclically loaded samples failed at a lower 

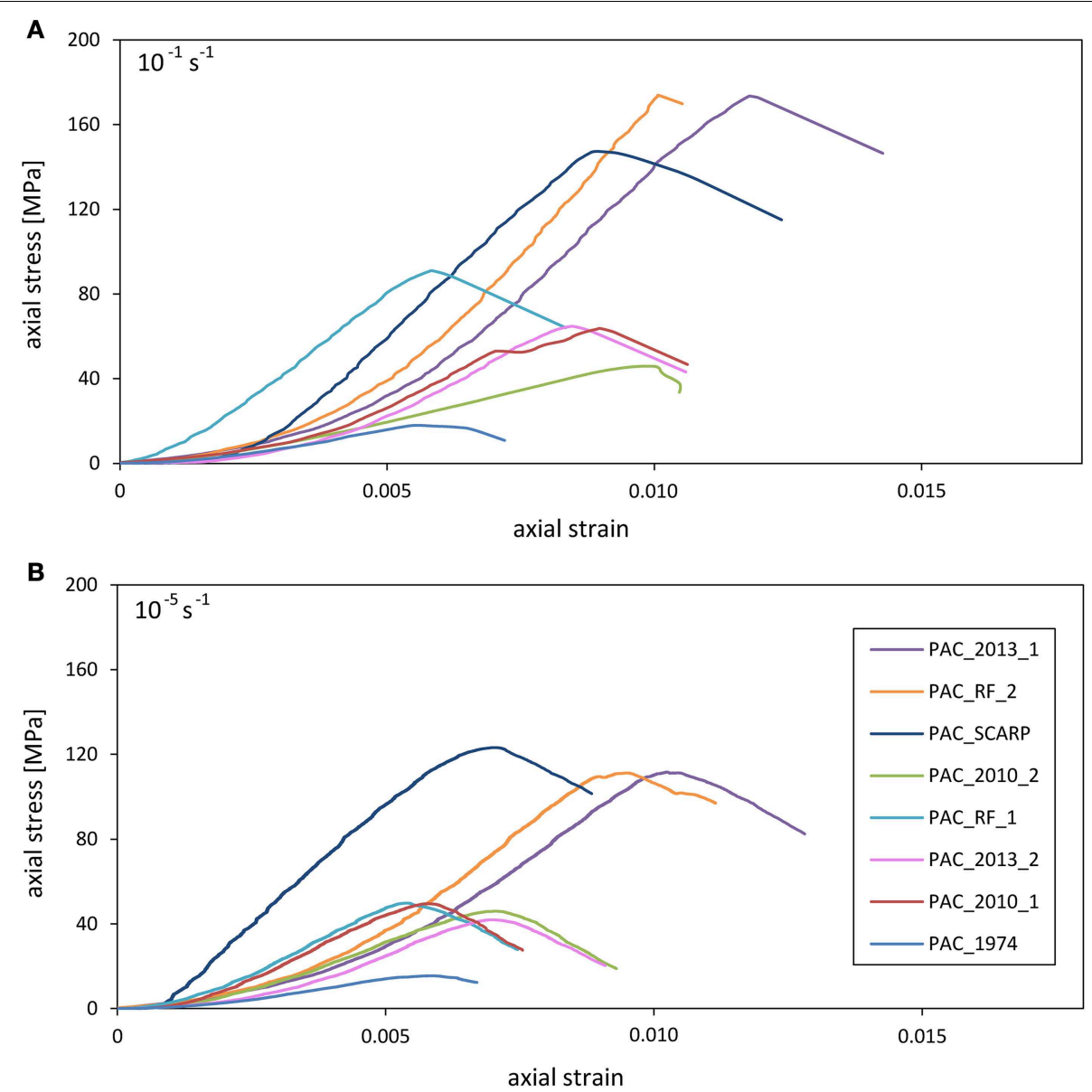

FIGURE 5 | Stress-strain curves for uniaxial compressive strength tests conducted on original cores (i.e., without thermal stressing) at room temperature and strain rates of (A) $10^{-1} \mathrm{~s}^{-1}$, and (B) $\mathbf{1 0}^{-5} \mathbf{s}^{-1}$. (A) Compression at this high constant strain rate, results in an initial compaction of the rock and closure of cracks (leading to an initially small stress build up despite a relatively large strain); beyond this point stress increases linearly until values approaching the peak stress, where the onset of strain hardening due to sample dilation is triggered by fracture nucleation, propagation, and coalescence, after which the test concludes with failure and a rapid stress drop. The data suggests that the densest rocks reached a higher peak stress and accumulated the most strain before yielding to failure. (B) Compression at a lower strain rate of $10^{-5} \mathrm{~s}^{-1}$, suggest a similar behavior although we note more strain hardening as the stress approaches the peak stress that results in sample failure and less distinct stress drops. stress than the peak stress experienced in the penultimate cycle (Figures 7C,D). Compared to the mechanical behavior of the rocks during standard UCS tests at strain rates of $10^{-5} \mathrm{~s}^{-1}$, four out of seven rocks failed at a lower stress during the cyclic tests, and five out of seven rocks failed at lower strain (Figure 8A). Continuous stress-strain curves (Figures 7B,D) show a degree of hysteresis, showing that at a given stress, strain is higher during unloading than during loading of a particular cycle. Each successive cycle led to further accumulated (non-recoverable) strain noted when the samples were unloaded to $5 \%$ of their value of their UCS (Figure 8B).

The effect of thermal stressing of cores varied across our investigated suite of samples: 12 out of 20 cores failed at a lower stress than the original samples (Table 3). The difference in porosity before and after thermal treatment was, however, minimal $(-0.4$ to $+0.2 \%)$ and overall, the changes in strength by thermal stressing are within the natural variability of each sample (Figures 6A,B). Additionally, there were no significant variations in the magnitude of strain to failure or style of failure upon thermal stressing (see Supplementary Information).

The deformation of rock at high-temperature exhibited an increase in strength. On average, strength at $935^{\circ} \mathrm{C}$ was 19 and $5 \%$ higher than the rock strength at room temperature for deformation at strain rates of $10^{-1}$ and $10^{-5} \mathrm{~s}^{-1}$, respectively. These tests revealed that rock failure at high temperature requires a higher magnitude of strain than at room temperature; this is especially the case for the lower porosity (strongest) samples (Figure 6A) The peak stress of these tests also scale inversely with porosity as do the tests at room temperature (Figure 6B).

Almost all the samples had a Young's Modulus that scaled approximately linearly to peak strength (Figure 9A), the only 


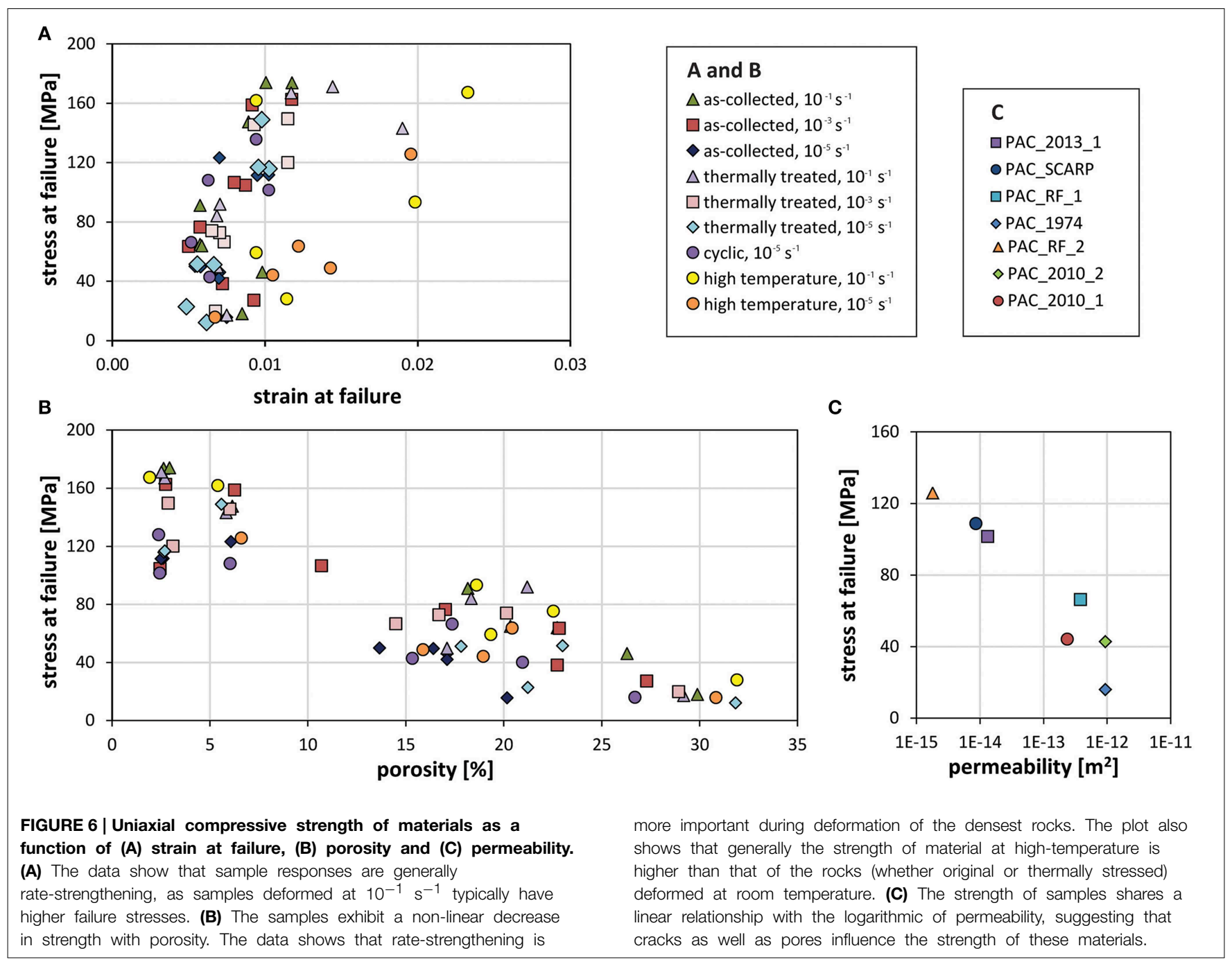

outliers were the high-temperature experiments, which had a lower Young's Modulus for a given compressive strength (Figure 9A). This difference becomes particularly prominent at higher strength, and corresponds to a slightly higher strain to failure, especially at low porosity (Figure 9B).

\section{Discussion}

Examination of the mechanical properties of eruptive products at Pacaya volcano provide us with a landscape of data from which to improve our understanding of volcano edifice properties. Of the attributes measured, porosity has the strongest control on rock strength, followed by strain rate, then temperature, which show non-negligible, second order effects. Cyclic loading and thermal stressing seem to have lesser, unsystematic influences on the mechanical behavior of the rocks tested (Figure 6B). The mechanical data show that the strength of the tested Pacaya basalts vary by slightly over one order of magnitude from 12 to $174 \mathrm{MPa}$ across a range of porosities from 2 to $48 \%$, corresponding to a permeability range of $10^{-12}-10^{-15} \mathrm{~m}^{2}$ for the experimental samples. Given that the samples tested here only represent coherent rocks forming the volcano (Figure 4A), it is likely that incoherent lithologies such as unconsolidated breccias (not studied experimentally, but for which we measured high permeabilities in the field; Figure 4A) have negligible strength, leading to presumably very weak layers which can be destabilized and jeopardize the stability of the volcano.

The wide range of strength in volcanic rocks is commonly attributed to varying compositions and microstructures inherent in volcanic rock (e.g., Byerlee, 1978; Heap et al., 2014b). Strength of materials has long been described as a function of their porosity (see Paterson and Wong, 2005). In volcanic rock, the porosity is made up of vesicles and microcracks and as such, the relationship presented between strength and permeability, though not commonly investigated, deserves consideration. Early theoretical efforts to model the mechanical properties of porous material have proposed models describing the process of failure for pore-bearing rocks, including the pore-emanated crack model (Sammis and Ashby, 1986), as well as the process of failure of crack-bearing rocks, including the wing-crack model (Ashby 
TABLE 3 | Summary of all results, including porosity, uniaxial compressive strength and Young's Modulus for each sample type by experiment I.D.

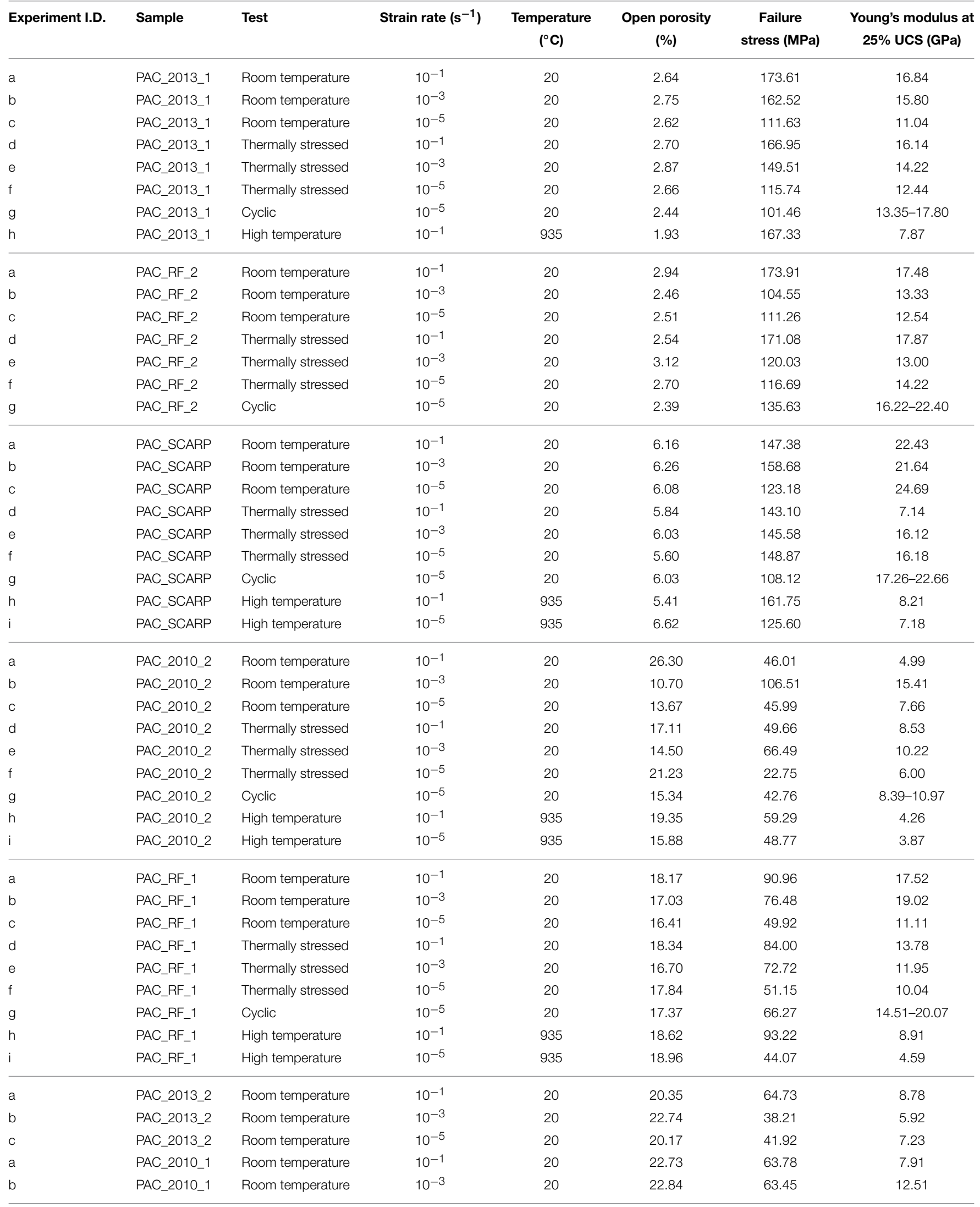


TABLE 3 | Continued

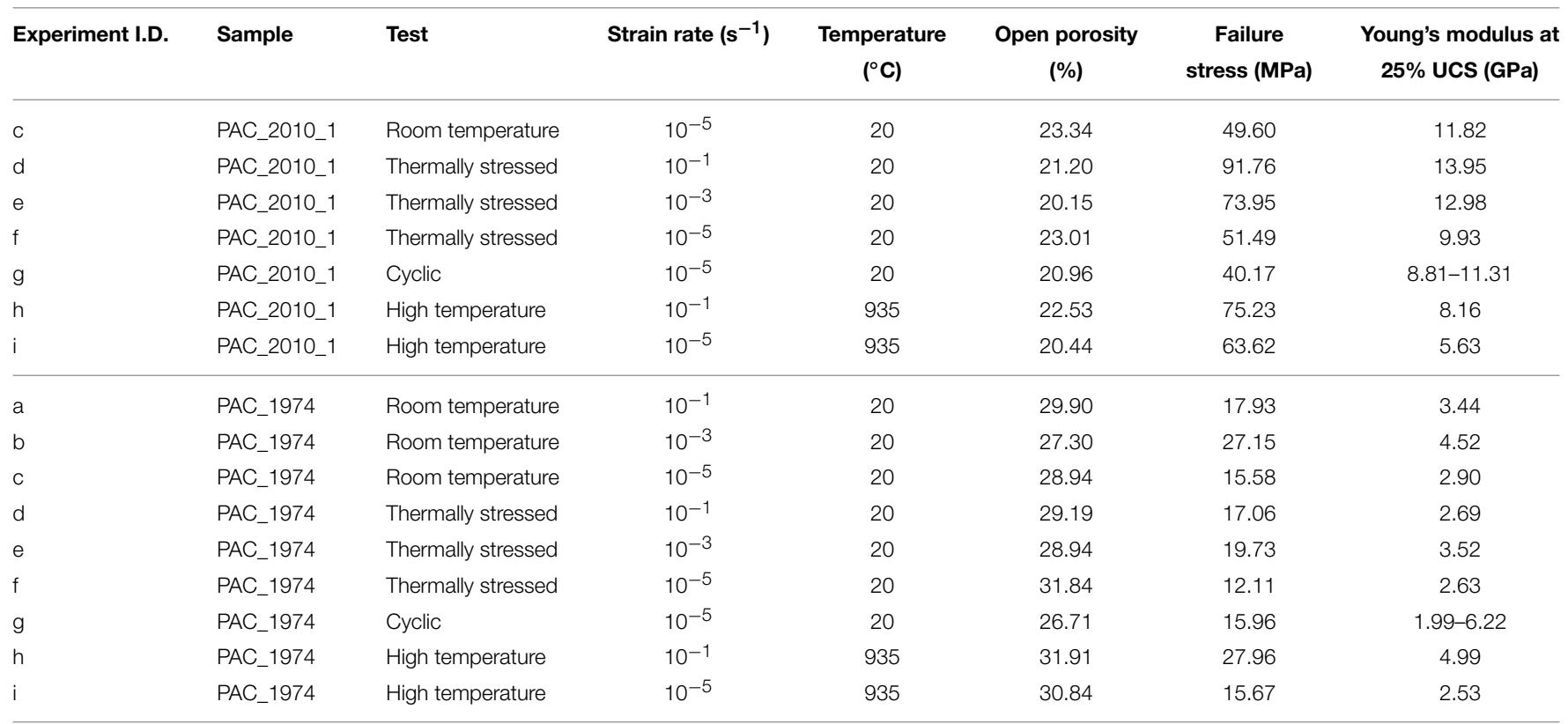
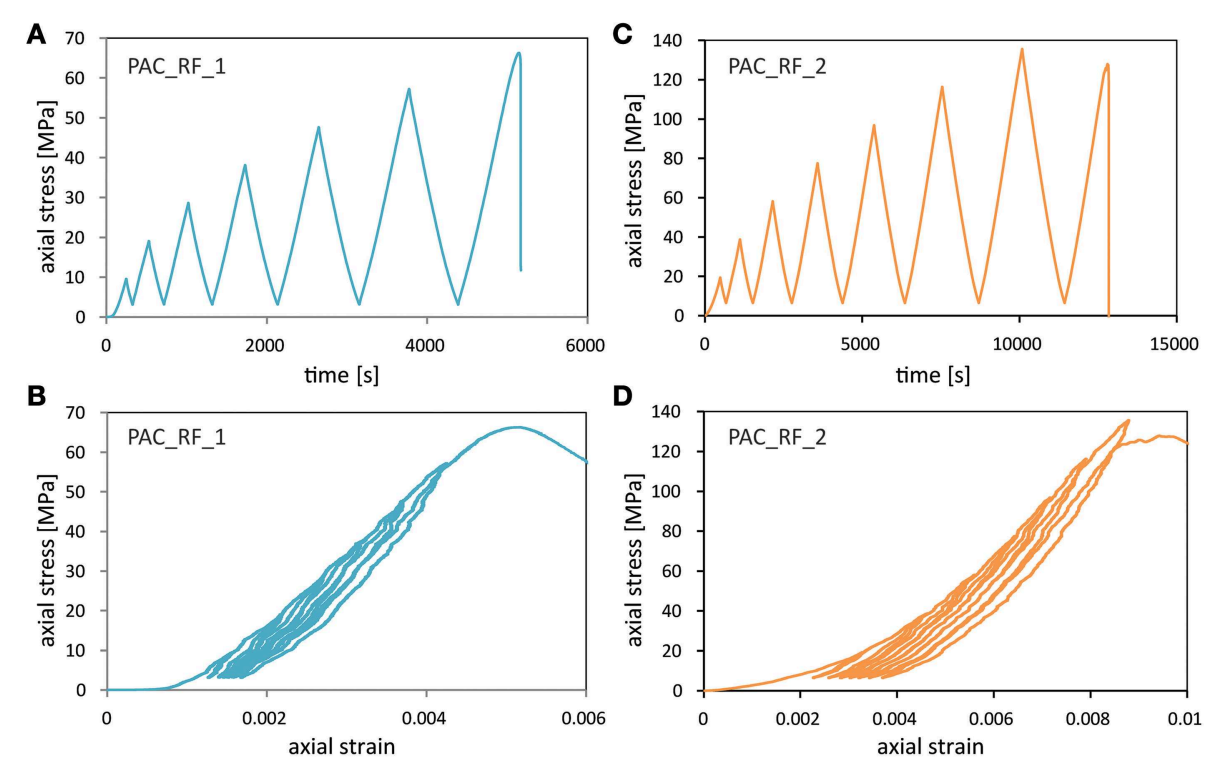

FIGURE 7 | Results from cyclic loading experiments in which each cycle reaches higher stress increments (set to $15 \%$ of the UCS) and is unloaded to $5 \%$ of the UCS between each cycle. Evolution of axial stress through time (A, C) and strain (B, D). (A) During cyclic loading of sample PAC_RF_1 deformed at $10^{-5} \mathrm{~s}^{-1}$ failure is achieved in the final cycle at a stress exceeding the stress value reached in the previous loading cycle.
(B) Cyclic deformation and unloading shows hysteresis as strain is accumulated. (C) During cyclic loading of sample PAC_RF_2 deformed at $10^{-5} s^{-1}$ failure is achieved at a stress lower than the peak stress reached in the penultimate cycle. (D) The sample is subjected to a stronger damage accumulation, and hysteresis, than sample PAC_RF_1, which may explain why this sample failed at a total stress lower than previously experienced. and Sammis, 1990). A recent micromechanical study of volcanic rock behavior suggested that the abundance of both vesicles and cracks in volcanic rocks thwart our ability to predict failure using these models (e.g., Heap et al., 2014b). Pores and cracks are fundamental to volcanic systems; the importance of permeability and its influence on gas release vs. build-up in a volcanic systems play an important role on the explosivity of an eruption (e.g., Mueller et al., 2005) but also structural stability (Thomas et al., 2004). Here, we suggest that the strength of rock and the character of the porous and permeable network are intrinsically related (Figure 4B) and influence the mechanical properties of volcanic edifices (Figures 6B,C). 


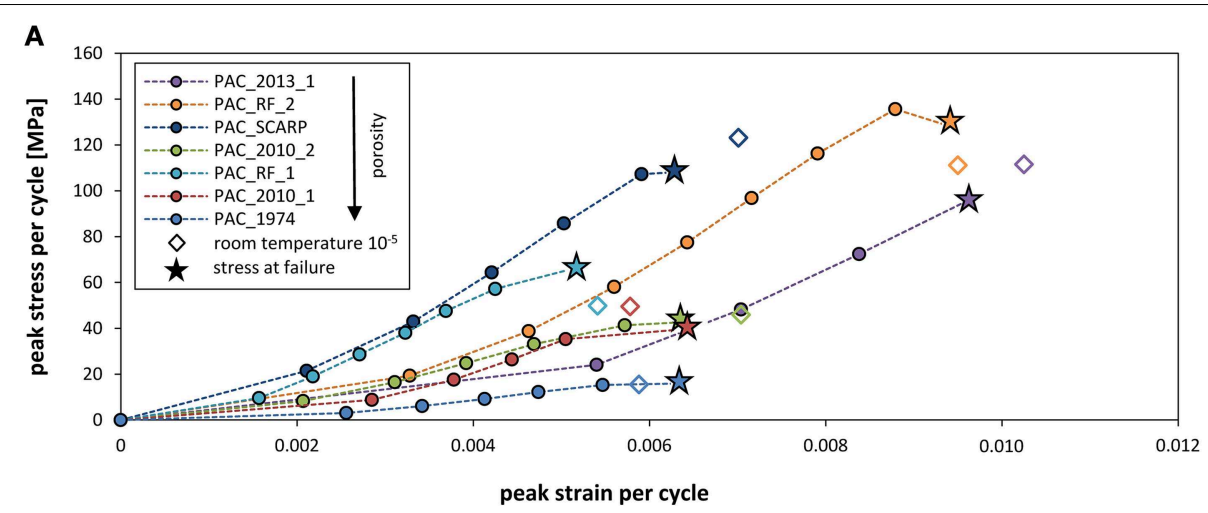

B

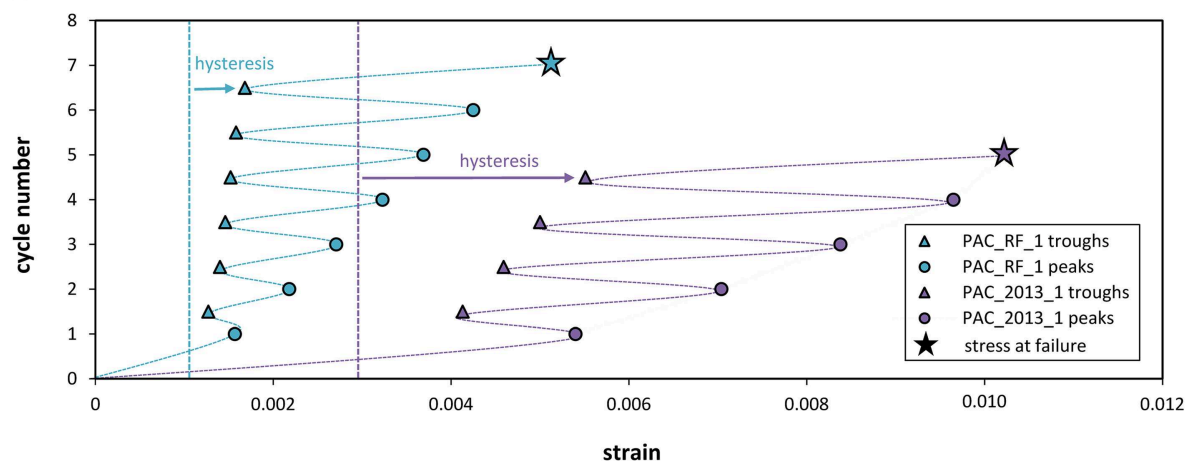

FIGURE 8 | Cyclic loading experiments; (A) Stress-strain evolution for all samples during cyclic loading until failure (shown as a star), as compared to the strength and strain at failure of original (non-thermally stressed) samples determined at room temperature (open diamond). The data shows that generally, the highest porosity samples fail at lower stress and strain. (B) Strain accumulation in samples requiring the lowest and highest strain to failure. Strain accumulation in each stress through highlights the hysteresis induced by the damage imparted. The hysteresis seems to be highest in the stronger, denser sample PAC_2013_1.
Strain-rate strengthening is observed and may be a result of increased elasticity as well as crack coalescence lagging behind axial deformation at faster rates (e.g., Jaeger and Cook, 1976). Strain-rate strengthening is observed across all conditions similar to previous studies on volcanic rocks (e.g., Rocchi et al., 2004), but is more effective at high temperature, as was suggested by Lindholm et al. (1974). The strain-rate effect implies that slow strain events, such as downslope movement, creep, or shallow magma pooling, could cause more pervasive damage and be more detrimental to the stability of an edifice than fast strain events such as dike intrusions or ground motion produced during earthquakes.

High temperature strengthening occurred across the sample set. While in some cases it is possible that chemical alteration, partial melting or viscous relaxation of interstitial glass may heal pre-existing fractures, we suggest that under the conditions investigated here, it is more plausible that increased strength relates to expansion and densification (via closure of cracks) and higher elasticity in molecular bonds (see Young's Modulus values, Table 3). For example, the experiment temperature (at $935^{\circ} \mathrm{C}$ ) is above the order-disorder transition of plagioclase, which is known to increase seismic velocities (Kono et al., 2008) and may correlate to increased elasticity. Indeed, here we show that rock deformation in a fully brittle regime at high temperatures experience significantly more strain to failure than at room temperature. This characteristic is not unique to the basalts at high temperature, though many other rock types often become weaker with temperature, especially if they undergo alteration (e.g., decarbonation, dehydroxylization; Heap et al., 2012, 2013a,b) or significant thermal expansion (e.g., due to anisotropic expansion in crystals; Meredith and Atkinson, 1982; Zhang et al., 2009).

Experiments conducted at high temperatures cause rocks to be stronger and more elastic, suggesting that areas near magma intrusions, or areas heated over prolonged periods of time, could experience more deformation before failure than previously inferred from knowledge of rock behavior at low temperatures. According to Ebmeier et al. (2013), a lack of surface deformation before eruptions at Pacaya suggests that magma rises directly from the base of the crust without a period of crustal storage. The high temperature effects may thus explain the trivial amount of pre-eruptive ground deformation associated with dike propagation and magma transport in cold rocks prior to eruption at Pacaya. When also considering the strain-rate strengthening effect, these relatively fast dike injection events could also lead to an increase in edifice elasticity, resulting in less pervasive damage and thus less detriment to the edifice forming rock. However, we must note that the results from cyclic experiments show 

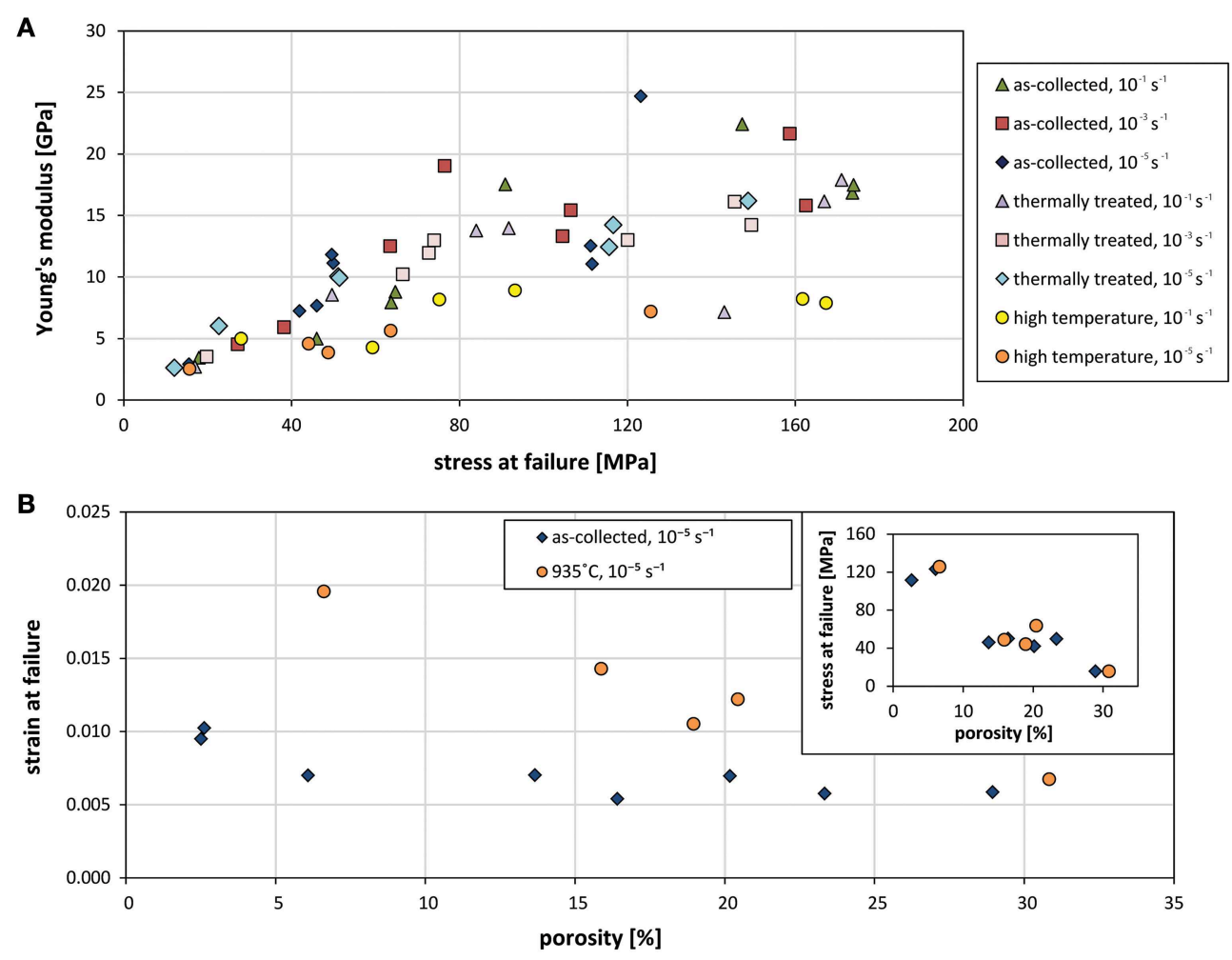

FIGURE 9 | (A) Static Young's Modulus plotted against the sample strength for all but the cyclically loaded samples. The results show that samples with higher Young's Modulus fail at higher stress, and typically deformation at a higher rate of $10^{-1} \mathrm{~s}^{-1}$ results in a higher apparent Young's Modulus. Noticeably, the material response during tests at high temperature display the lowest Young's Moduli, which correlate with the observation that (B) at high temperature more strain is required to achieve failure than at room temperature; this, despite only a mild strengthening of the material at high temperature (insert). that if dikes are continually intruded, the country rock could be mechanically weakened over time through strain accumulation, particularly in areas with high elastic modulus values.

Thermally stressing rocks has a complex effect on strength: some cores were slightly weakened, while others were slightly strengthened post-heat treatment. The variable effect of thermal stressing at similar temperatures has also been noted by changes in crack content in other rocks such as andesite (Heap et al., 2014a) and granite (Wang et al., 2013). Although heating and cooling can both induce cracking, there seems to be no systematic response as a function of starting porosity. Volcanic rocks form by cooling and as such, their microstructures and importantly here, microcracks, preserve a record of the cooling history. In our study, the cores were heated and cooled at a rate likely lower than that experienced during cooling upon eruption; it is possible that such mild thermal conditions would minimize the extent of crack damage overprint. According to Heap et al. (2009), so long as the mineralogical assemblage remains intact, microcracks (and subsequent weakening) induced by thermal stressing are likely a function of the original thermal stressing imposed by natural cooling; that is, thermal stressing must be applied at a rate that exceeds natural cooling rate to induce significant damage. Recent studies assessing the effect of fractures induced by thermal stressing concluded that its occurrence would likely not (significantly) affect volcanic edifice stability (Vinciguerra et al., 2005; Heap et al., 2009; Kendrick et al., 2013b). However, we point out that additional mechanical stresses resulting from magmatic forcing during transport would create a zone of damage, increasing the overall heterogeneity of the edifice.

Cyclic loading tests had a variable effect on failure stress and strain, however, they do suggest that repeated dike intrusion or inflation and deflation has the potential to cause edifice weakening by imparting a permanent strain on rocks. The stressstrain curves show hysteresis, and during unloading to $5 \%$ of the peak failure stress, the strain remains above zero and gradually increases from cycle to cycle (Figure 8). Such behavior has been observed in other volcanic rocks, including andesite (Kendrick et al., 2013a) and basalt (Heap et al., 2009, 2010), along with sedimentary rocks (e.g., sandstone; Song et al., 2013). Our work further suggests that material with porosities above 5 vol. \% can typically absorb stress with fewer permanent damage accumulation (Figure 5B). This elastic response may result from compressibility of the rocks into the porous space, attempting to shut the cracks and vesicles. Elastic response may also be due to changes in porosity isolation as pores are connected through microcracking, with the resultant higher connected porosity allowing for more fluid stress compensation between pores, simultaneously preventing stiffening. This effect would 
be more abundant in rocks with higher porosity. According to Gurevich (2003), approximately $10 \%$ porosity or greater provides enough space for fluid to flow into pores and escape fracture. The implications of cyclic loading/ unloading suggest that volcanic rocks may not behave entirely elastically and accumulate damage. Once imparted, damage in turn affects the resultant material response to stress (changes in strength and Young's modulus), which may favor stress rotation (e.g., Faulkner et al., 2006), with potentially more widespread consequences on the distribution of stress in the edifice.

\section{Conclusions}

An experimental investigation of the mechanical properties of basalts at Pacaya volcano has been undertaken to increase our knowledge of contributing variables on slope stability in volcanic edifices. The rocks forming Pacaya volcano are heterogeneous at a range of scales: at the edifice scale, we find the main lithologies are locally heterogeneous due to the limited spread of lava flows as well as to flow emplacement inside earlier collapse scars; at the rock scale, we find that the rocks are macroscopically and microscopically heterogeneous, showing little variation in mineralogy, but strong variation in textures, porosities (formed of pores and cracks) and permeability. The permeability is constrained to increase non-linearly with

\section{References}

Al-Harthi, A. A., Al-Amri, R. M., and Shehata, W. M. (1999). The porosity and engineering properties of vesicular basalt in Saudi Arabia. Eng. Geo. 54, 313-320. doi: 10.1016/S0013-7952(99)00050-2

Apuani, T., and Corazzato, C. (2010). "Etna flank dynamics: a sensitivity analysis by numerical modeling" in ISRM International Workshop on Rock Mechanics and Geoengineering in Volcanic Environments (Puerto de la Cruz: International Society for Rock Mechanics).

Apuani, T., Corazzato, C., Cancelli, A., and Tibaldi, A. (2005a). Physical and mechanical properties of rock masses at Stromboli: a dataset for volcano instability evaluation. Bull. Eng. Geol. Environ. 64, 419-431. doi: 10.1007/s10064-005-0007-0

Apuani, T., Corazzato, C., Cancelli, A., and Tibaldi, A. (2005b). Stability of a collapsing volcano (Stromboli-Italy): limit equilibrium analysis and numerical modelling. J. Volcanol. Geotherm. Res. 144, 191-210. doi: 10.1016/j.jvolgeores.2004.11.028

Apuani, T., Merri, A., and Masetti, M. (2007). "Effects of volcanic seismic events on the Stromboli stability by finite difference numerical modeling" in Proceedings of the International Workshop on Volcanic Rocks. 11th ISRM Congress (Ponta Delgada), 101-109.

Ashby, M. F., and Sammis, C. G. (1990). The damage mechanics of brittle solids in compression. Pure Appl. Geophys. 133, 489-521. doi: 10.1007/BF00878002

Ashwell, P. A., Kendrick, J. E., Lavallée, Y., Kennedy, B. M., Hess, K. U., von Aulock, F. W., et al. (2015). Permeability of compacting porous lavas. J. Geophys. Res. Solid. Earth 120, 1605-1622. doi: 10.1002/2014jb011519

Balme, M. R., Rocchi, V., Jones, C., Sammonds, P. R., Meredith, P. G., and Boon, S. (2004). Fracture toughness measurements on igneous rocks using a high pressure, high temperature rock fracture mechanics cell. J. Volcanol. Geotherm. Res. 132, 159-172. doi: 10.1016/S0377-0273(03) 00343-3

Bardintzeff, J., and Deniel, C. (1992). Magmatic evolution of Pacaya and Cerro Chiquito volcanological complex, Guatemala. Bull. Volcanol. 54, 267-283. doi: 10.1007/BF00301482 porosity. Laboratory testing of the mechanical behavior shows that the strength decreases with porosity, increases with strain rate, increases with ambient (deformation) temperature, and is unsystematically varied by both thermal stressing, and due to prolonged stressing histories where cycles of loading/ unloading can induce mechanical hysteresis. We anticipate that integration of such process-specific rock properties in modeling of volcanic events will improve hazard analysis interpretation at active volcanoes such as Pacaya.

\section{Acknowledgments}

LS would like to recognize support provided by the NASA Earth and Space Science Fellowship Program (no. NNX13AO50H) and the AEG Foundation. JK and YL acknowledge support from the European Research Council Starting Grant on Strain Localization in Magma (SLiM; No. 306488). We would like to thank Oleg E. Melnik and Corrado Cimarelli for their constructive reviews of this manuscript.

\section{Supplementary Material}

The Supplementary Material for this article can be found online at: http://journal.frontiersin.org/article/10.3389/feart. 2015.00029/abstract

Batzle, M. L., Simmons, G., and Siegfried, R. W. (1980). Microcrack closure in rocks under stress: direct observation. J. Geophys. Res. Solid. Earth 85, 7072-7090. doi: 10.1029/JB085iB12p07072

Bauer, S. J., Friedman, M., and Handin, J. (1981). "Effects of water-saturated on strength and ductility of three igneous rocks at effective pressures to $50 \mathrm{MPa}$ and temperatures to partial melting," in Rock Mechanics from Research to Application, eds H. H. Einstein and D. P. Scandriato (Rotterdam: Balkema), 79-84.

Benson, P. M., Vinciguerra, S., Meredith, P. G., and Young, R. P. (2008) Laboratory simulation of volcano seismicity. Science 322, 249-252. doi: $10.1126 /$ science. 1161927

Byerlee, J. (1978). Friction of rocks. Pure Appl. Geophys. 116, 615-626. doi: 10.1007/BF00876528

Cordonnier, B., Hess, K. U., Lavallée, Y., and Dingwell, D. B. (2009). Rheological properties of dome lavas: case study of Unzen volcano. Earth Planet Sci. Lett. 279, 263-272. doi: 10.1016/j.epsl.2009.01.014

del Potro, R., and Hürlimann, M. (2008). Geotechnical classification and characterization of materials for stability analyses of large volcanic slopes. Eng. Geol. 98, 1-17. doi: 10.1016/j.enggeo.2007.11.007

del Potro, R., Hürlimann, M., and Pinkerton, H. (2013). Modelling flank instabilities on stratovolcanoes: parameter sensitivity and stability analyses of Teide, Tenerife. J. Volcanol. Geotherm. Res. 256, 50-60. doi: 10.1016/j.jvolgeores.2013.02.003

Donnadieu, F., Merle, O., and Besson, J. C. (2001). Volcanic edifice stability during cryptodome intrusion. Bull. Volcanol. 63, 61-72. doi: 10.1007/s004450 000122

Ebmeier, S. K., Biggs, J., Mather, T. A., and Amelung, F. (2013). Applicability of InSAR to tropical volcanoes: insights from Central America. Geol. Soc. Lond. Spec. Publ. 380, 15-37. doi: 10.1144/SP380.2

Eggers, A. (1983). Temporal Gravity and Elevation Changes at Pacaya Volcano, Guatemala. Ph.D. dissertation, Dartmouth College.

Elsworth, D., and Voight, B. (1996). Evaluation of volcano flank instability triggered by dyke intrusion. Geol. Soc. Lond. Spec. Publ. 110, 45-53. doi: 10.1144/GSL.SP.1996.110.01.03 
Faulkner, D. R., Mitchell, T. M., Healy, D., and Heap, M. J. (2006). Slip on 'weak' faults by the rotation of regional stress in the fracture damage zone. Nature 444, 922-925. doi: 10.1038/nature05353

Fredrich, J. T., and Wong, T. F. (1986). Micromechanics of thermally induced cracking in three crustal rocks. J. Geophys. Res. 91, 12743-12764. doi: 10.1029/JB091iB12p12743

Griggs, D. T., Turner, F. J., and Heard, H. C. (1960). Chapter 4: deformation of Rocks at $500^{\circ}$ to $800^{\circ}$ C. Geol. Soc. Am. Mem. 79, 39-104. doi: 10.1130/ mem79-p39

Gurevich, B. (2003). Elastic properties of saturated porous rocks with aligned fractures. J. Appl. Geophys. 54, 203-218. doi: 10.1016/j.jappgeo.2002.11.002

Handin, J., and Carter, N. (1979). Rheological properties of rock at high temperatures. Proc. Congr. Int. Soc. Rock. Mech. 4, 97-106.

Heap, M. J., and Faulkner, D. R. (2008). Quantifying the evolution of static elastic properties as crystalline rock approaches failure. Int. J. Rock Mech. Min. 45, 564-573. doi: 10.1016/j.ijrmms.2007.07.018

Heap, M. J., Faulkner, D. R., Meredith, P. G., and Vinciguerra, S. (2010). Elastic moduli evolution and accompanying stress changes with increasing crack damage: implications for stress changes around fault zones and volcanoes during deformation. Geophys. J. Int. 183, 225-236. doi: 10.1111/j.1365246X.2010.04726.X

Heap, M. J., Lavallée, Y., Laumann, A., Hess, K.-U., Meredith, P. G., and Dingwell, D. B. (2012). How tough is tuff in the event of fire. Geology 40, 311-314. doi: $10.1130 / \mathrm{G} 32940.1$

Heap, M. J., Lavallée, Y., Meredith, P. G., Dingwell, D. B., Huismann, S., and Weise, F. (2013b). The influence of thermal-stressing on the physical, mechanical and chemical properties of siliceous-aggregate high-strength concrete. Constr. Build. Mater. 42, 248-265. doi: 10.1016/j.conbuildmat. 2013.01.020

Heap, M. J., Lavallée, Y., Petrakova, L., Baud, P., Reuschlé, T., Varley, N. R., et al. (2014a). Microstructural controls on the physical and mechanical properties of edifice-forming andesites at Volcán de Colima, Mexico. J. Geophys. Res. Solid. Earth 119, 2925-2963. doi: 10.1002/2013JB010521

Heap, M. J., Mollo, S., Vinciguerra, S., Lavallée, Y., Hess, K.-U., Dingwell, D. B., et al. (2013a). Thermal weakening of the carbonate basement under Mt. Etna volcano (Italy): implications for volcano instability. J. Volcanol. Geotherm. Res. 250, 42-60. doi: 10.1016/j.jvolgeores.2012.10.004

Heap, M. J., Vinciguerra, S., and Meredith, P. G. (2009). The evolution of elastic moduli with increasing crack damage during cyclic stressing of a basalt from Mt. Etna volcano. Tectonophysics 471, 153-160. doi: 10.1016/j.tecto.2008.10.004

Heap, M., Xu, T., and Chen, C.-F. (2014b). The influence of porosity and vesicle size on the brittle strength of volcanic rocks and magma. Bull. Volcanol. 76, 1-15. doi: 10.1007/s00445-014-0856-0

Hoek, E. (1994). Strength of rock and rock masses. ISRM News J. 2, 4-16.

Hürlimann, M., Mart, J., and Ledesma, A. (2000). Mechanical relationship between catastrophic volcanic landslides and caldera collapse. Geophys. Res. Lett. 27, 2393-2396. doi: 10.1029/2000GL011564

Iverson, R. (1995). Can magma-injection and groundwater forces cause massive landslides on Hawaiian volcanoes? J. Volcanol. Geotherm. Res. 66, 295-308.

Jaeger, J. C., and Cook, N. G. W. (1976). Fundamentals of Rock Mechanics. London: Chapman and Hall.

Jones, C., Keaney, G., Meredith, P. G., and Murrell, S. A. F. (1997). Acoustic emission and fluid permeability measurements on thermally cracked rocks. Phys. Chem. Earth 22, 13-17.

Kendrick, J. E., Lavallée, Y., Hess, K. U., Heap, M. J., Gaunt, H. E., Meredith, P. G., et al. (2013b). Tracking the permeable porous network during straindependent magmatic flow. J. Volcanol. Geotherm. Res. 260, 117-126. doi: 10.1016/j.jvolgeores.2013.05.012

Kendrick, J. E., Smith, R., Sammonds, P., Meredith, P. G., Dainty, M., and Pallister, J. D. (2013a). The influence of thermal and cyclic stressing on the strength of rock from Mount St. Helens, Washington. Bull. Volcanol. 75, 1-12. doi: 10.1007/s00445-013-0728-Z

Kitamura, S., and Matías Gomez, O. (1995). Tephra Stratigraphic Approach to the Eruptive History of Pacaya Volcano, Guatemala. Science Reports-Tohoku University, Seventh Series: Geography, 45, 1-41.

Kono, Y., Miyake, A., Ishikawa, M., and Arima, M. (2008). Temperature derivatives of elastic wave velocities in plagioclase (An51 \pm 1$)$ above and below the order-disorder transition temperature. Am Mineral. 93, 558-564. doi: 10.2138/am.2008.2591

Kueppers, U., Scheu, B., Spieler, O., and Dingwell, D. B. (2006). Fragmentation efficiency of explosive volcanic eruptions: a study of experimentally generated pyroclasts. J. Volcanol. Geotherm. Res. 153, 125-135. doi: 10.1016/j.jvolgeores.2005.08.006

Lavallée, Y., Hess, K. U., Cordonnier, B., and Dingwell, D. B. (2007). NonNewtonian rheological law for highly crystalline dome lavas. Geology 35, 843-846. doi: 10.1130/G23594A.1

Lavallée, Y., Meredith, P. G., Dingwell, D. B., Hess, K. U., Wassermann, J., Cordonnier, B., et al. (2008). Seismogenic lavas and explosive eruption forecasting. Nature 453, 507-510. doi: 10.1038/nature06980

Lindholm, U. S., Yeakley, L. M., and Nagy, A. (1974). The dynamic strength and fracture properties of dresser basalt. Int. J. Rock Mech. Min. 11, 181-191. doi: 10.1016/0148-9062(74)90885-7

Loaiza, S., Fortin, J., Schubnel, A., Gueguen, Y., Vinciguerra, S., and Moreira, M. (2012). Mechanical behavior and localized failure modes in a porous basalt from the Azores. Geophys. Res. Lett. 39, 6. doi: 10.1029/2012gl053218

Matías Gómez, R. O. (2009). Volcanological Map of the 1961-2009 Eruption of Volcán de Pacaya, Guatemala. M.S. thesis, Michigan Technological University, Guatemala.

Matías Gómez, R. O., Rose, W. I., Palma, J. L., and Escobar-Wolf, R. (2012). Notes on a map of the 1961-2010 eruptions of Volcán de Pacaya, Guatemala. Geol. Soc. Am. Digit. Map Chart Ser. 10, 10. doi: 10.1130/2012.DMCH010

Meredith, P. G., and Atkinson, B. K. (1982). High-temperature tensile crack propagation in quartz: experimental results and application to time-dependent earthquake rupture, Earthquake. Predic. Res. 1, 377-391.

Merriam, R., Rieke, H. H., and Kim, Y. C. (1970). Tensile strength related to mineralogy and texture of some granitic rocks. Eng. Geo. 4, 155-160. doi: 10.1016/0013-7952(70)90010-4

Mueller, S., Melnik, O., Spieler, O., Scheu, B., and Dingwell, D. B. (2005). Permeability and degassing of dome lavas undergoing rapid decompression: an experimental determination. Bull. Volcanol. 67, 526-538. doi: 10.1007/s00445004-0392-4

Okubo, C. H. (2004). Rock mass strength and slope stability of the Hilina slump, Kilauea volcano, Hawaii. J. Volcanol. Geotherm. Res. 138, 43-76. doi: 10.1016/j.jvolgeores.2004.06.006

Paterson, M. S., and Wong, T. F. (2005). Experimental Rock Deformation-the Brittle Field. Berlin; Heidelberg: Springer Science and Business Media.

Prrikryl, R. (2001). Some microstructural aspects of strength variation in rocks. Int. J. Rock Mech. Min. 38, 671-682. doi: 10.1016/S1365-1609(01)00031-4

Reid, M. E., Christian, S. B., and Brien, D. L. (2000). Gravitational stability of three-dimensional stratovolcano edifices. J. Geophys. Res. 105, 6043-6056. doi: 10.1029/1999JB900310

Rocchi, V., Sammonds, P. R., and Kilburn, C. R. (2003). Flow and fracture maps for basaltic rock deformation at high temperatures. J. Volcanol. Geotherm. Res. 120, 25-42. doi: 10.1016/S0377-0273(02)00343-8

Rocchi, V., Sammonds, P. R., and Kilburn, C. R. J. (2004). Fracturing of Etnean and Vesuvian rocks at high temperatures and low pressures. J. Volcanol. Geotherm. Res. 132, 137-157. doi: 10.1016/S0377-0273(03)00342-1

Rose, W. I., Palma, J. L., Escobar Wolf, R., and Matías Gomez, R. O. (2013). A 50 yr eruption of a basaltic composite cone: Pacaya, Guatemala. Geol. S. Am. S. 498, 1-21. doi: 10.1130/2013.2498(01)

Sammis, C. G., and Ashby, M. F. (1986). The failure of brittle porous solids under compressive stress states. Acta. Metall. 34, 511-526. doi: 10.1016/00016160(86)90087-8

Schaefer, L. N., Oommen, T., Corazzato, C., Tibaldi, A., Escobar-Wolf, R., and Rose, W. I. (2013). An integrated field-numerical approach to assess slope stability hazards at volcanoes: the examples of Pacaya Volcano, Guatemala. Bull. Volcanol. 75, 1-18. doi: 10.1007/s00445-013-0720-7

Scheu, B., Kueppers, U., Mueller, S., Spieler, O., and Dingwell, D. B. (2008). Experimental volcanology on eruptive products of Unzen volcano. J. Volcanol. Geotherm. Res. 175, 110-119. doi: 10.1016/j.jvolgeores.2008. 03.023

Scholz, C. H. (1968). Microfracturing and the inelastic deformation of rock in compre ssion. J. Geophys. Res. 73, 1417-1432. doi: 10.1029/JB073i004p01417

Simmons, G., and Cooper, H. W. (1978). Thermal cycling cracks in three igneous rocks. Int. J. Rock Mech. Min. 15, 145-148. doi: 10.1016/0148-9062(78)91220-2 
Smith, R., Sammonds, P. R., and Kilburn, C. R. (2005). "Experimental studies of lava dome fracture," in AGU Fall Meeting Abstracts (San Francisco, CA), 1.

Song, H., Zhang, H., Kang, Y., Huang, G., Fu, D., and Qu, C. (2013). Damage evolution study of sandstone by cyclic uniaxial test and digital image correlation. Tectonophysics 608, 1343-1348. doi: 10.1016/j.tecto.2013. 06.007

Sousa, J., and Voight, B. (1995). Multiple-pulsed debris avalanche emplacement at Mount St. Helens in 1980: evidence from numerical continuum flow simulations. J. Volcanol. Geotherm. Res. 66, 227-250. doi: 10.1016/03770273(94)00067-Q

Spieler, O., Kennedy, B., Kueppers, U., Dingwell, D. B., Scheu, B., and Taddeucci, J. (2004). The fragmentation threshold of pyroclastic rocks. Earth Planet Sci. Lett. 226, 139-148. doi: 10.1016/j.epsl.2004.07.016

Tapponnier, P., and Brace, W. F. (1976). Development of stress-induced microcracks in Westerly granite. Int. J. Rock Mech. Min. 13, 103-112. doi: 10.1016/0148-9062(76)91937-9

Thomas, M. E., Petford, N., and Bromhead, E. N. (2004). Volcanic rockmass properties from Snowdonia and Tenerife: implications for volcano edifice strength. J. Geol. Soc. Lond. 161, 939-946. doi: 10.1144/0016764903-166

Vallance, J. W., Siebert, L., Rose, W. I., Raul Girón, J., and Banks, N. G. (1995). Edifice collapse and related hazards in Guatemala. J. Volcanol. Geotherm. Res. 66, 337-355. doi: 10.1016/0377-0273(94)00076-S

Vinciguerra, S., Trovato, C., Meredith, P. G., and Benson, P. M. (2005). Relating seismic velocities, thermal cracking and permeability in Mt. Etna and Iceland basalts. Int. J. Rock Mech. Min. Sci. 42, 900-910. doi: 10.1016/j.ijrmms.2005.05.022
Voight, B., Janda, R. J., Glicken, H., and Douglass, P. M. (1983). Nature and mechanics of the Mount St Helens rockslide-avalanche of 18 May 1980. Géotechnique 33, 243-273. doi: 10.1680/geot.1983.33.3.243

Wang, X. Q., Schubnel, A., Fortin, J., Guéguen, Y., and Ge, H. K. (2013). Physical properties and brittle strength of thermally cracked granite under confinement. J. Geophys. Res. Solid Earth 118, 6099-6112. doi: 10.1002/2013JB010340

Wunderman, R. L., and Rose, W. I. (1984). Amatitlán, an actively resurging cauldron $10 \mathrm{~km}$ south of Guatemala City. J. Geophys. Res. Solid Earth 89, 8525-8539. doi: 10.1029/JB089iB10p08525

Zhang, L., Mao, X., and Lu, A. (2009). Experimental study on the mechanical properties of rocks at high temperature. Sci. China Ser. E 52, 641-646. doi: 10.1007/s11431-009-0063-y

Zimbelman, D. R., Watters, R. J., Firth, I. R., Breit, G. N., and CarrascoNunez, G. (2004). Stratovolcano stability assessment methods and results from Citlaltépetl, Mexico. Bull. Volcanol. 66, 66-79. doi: 10.1007/s00445-003-0296-8

Conflict of Interest Statement: The authors declare that the research was conducted in the absence of any commercial or financial relationships that could be construed as a potential conflict of interest.

Copyright $\odot 2015$ Schaefer, Kendrick, Oommen, Lavallée and Chigna. This is an open-access article distributed under the terms of the Creative Commons Attribution License (CC BY). The use, distribution or reproduction in other forums is permitted, provided the original author(s) or licensor are credited and that the original publication in this journal is cited, in accordance with accepted academic practice. No use, distribution or reproduction is permitted which does not comply with these terms. 